\title{
Pemurnian Parsial dan Kritalisasi Papain dari Getah Carica papaya
}

\author{
Dwi Putri Mashfufatur Rohmah, Sofijan Hadi, Afaf Baktir ${ }^{*}$ \\ Departemen Kimia, Fakultas Sains dan Teknologi \\ Universitas Airlangga \\ *email: afaf-b@fst.unair.ac.id
}

Received 29 November 2019

Accepted 31 December 2019

\begin{abstract}
This research has done partial purification by fractionation and optimization crystallization of papain from Carica papaya latex with the addition of ammonium sulphate. The enhancement of purification factor was determined by its specific activity. The fractionation results show that papain fraction of Carica papaya can be obtained by adding $40-80 \%$ saturated ammonium sulphate, with the highest specific activity, i.e. 2,0819 U/ $\mu \mathrm{g}$ and the factor purification increase of 6,27 fold than papain extract. Meanwhile, the highest total activity, i.e. $10,7780 \mathrm{U}$ of papain crystals can be obtained by presipitant agent addition of ammonium sulphate in the level / concentration $80 \%$ saturated at $15{ }^{\circ} \mathrm{C}$. Microscopycally papain crystals profile in this condition have cube and tetragonal shape.
\end{abstract}

Keywords: Crystallization, fractionation, ammonium sulphate, papain

\section{Pendahuluan}

Dewasa ini, enzim memiliki peran besar dalam pengaplikasiannya di bidang agrikultural maupun bidang industri. Enzim digunakan sebagai alternatif untuk menggantikan berbagai proses kimia dalam bidang industri. Hal ini dikarenakan sifatnya yang efisien, selektif, predictable, dan ramah lingkungan. Bahkan dalam beberapa aplikasinya, enzim dinyatakan lebih ekonomis dibandingkan katalis kimia karena dapat digunakan secara berulang selama aktivitasnya masih ada (Sutandi, 2003; Zusfahair dkk., 2014). Salah satu enzim yang mendominasi pasar dunia sebesar $60 \%$ adalah protease. Enzim ini biasanya ditemukan dalam buah-buahan tropis maupun subtropis, seperti papaya, kiwi, dan nanas (Malek dkk., 2016; Zusfahair dkk., 2014).

Indonesia merupakan salah satu negara beriklim tropis dengan sebaran pertumbuhan papaya hampir di seluruh wilayah. Produksi papaya di Indonesia mencapai 840,112 ton menurut pantauan terakhir oleh Kementerian Pertanian
Indonesia pada tahun 2014. Hal tersebut menunjukkan adanya potensi yang besar untuk produksi enzim protease di Indonesia dengan sumber daya yang mendukung.

Protease dibedakan sesuai jenis gugus fungsi pada sisi aktifnya, salah satunya yaitu gugus tiol-sistein. Protease dengan jenis gugus fungsi tersebut termasuk protease sistein. Protease sistein ini juga dikenal sebagai protease tiol yang memiliki peran utama (primer) dalam degradasi dan pemecahan protein. pepaya (Latin: Carica papaya) telah diketahui menjadi sumber utama protease sistein dari penelitian yang dilakukan oleh Malek dkk. (2016).

Getah pada daging buah papaya muda, daun, dan kulitnya kaya akan enzim yang dikenal sebagai papain. Getah Carica papaya terdiri dari campuran endopeptidase sistein seperti papain, endopeptidase III papaya, endopeptidase IV papaya, caricain, kemopapain A dan B, serta proteinase IV papaya yang menyusun lebih dari $80 \%$ fraksi enzim yang 
dipertimbangkan menjadi bahan komersil dengan nilai tertinggi, mengingat kegunaannya dalam berbagai aplikasi di industri. Di antara enzim tersebut, papain menjadi sumber utama data empiris dari super-famili protease sistein dengan karakterisasi paling luas terkait data kinetiknya dan struktur enzimnya (Malek dkk., 2016).

Papain merupakan protein globular dengan rantai tunggal dan 3 jembatan disulfida serta gugus sulfhidril pada sisi aktifnya (Patel, 2016). Papain memiliki berat molekul 23.406 Da dan terdiri dari 212 asam amino (Gunde dan Amnerkar, 2016). Sifat yang sangat menarik dari papain adalah kestabilannya ketika terpapar suhu yang tinggi, pelarut organik, dan reagen-reagen yang dapat menyebabkan denaturasi pada enzim lain (Llerena-Suster dkk., 2012).

Pemurnian papain telah berhasil dicapai secara konvensional dengan metode presipitasi. Presipitasi dapat dilakukan dengan salting out menggunakan garam ammonium sulfat. Salting out merupakan penggaraman protein sehingga terjadi agregasi karena efek hidrofobik yang kuat dan terstabilkan. Molekul air disekitar residu hidrofobik protein akan dipindahkan ke permukaan, sehingga residu-residu hidrofobik dapat berinteraksi satu sama lain membentuk agregat (Scopes, 2013).

Enzim dalam bentuk kristal memiliki ketahanan yang jauh lebih baik terhadap pengaruh lingkungan (suhu, $\mathrm{pH}$, pengaruh oksidasi, dan lain-lain) sehingga perlakuan dan penyimpanannya akan lebih mudah serta bertahan lebih lama. Kristalisasi setiap molekul maupun campuran senyawa kimia, termasuk protein terdiri dari dua tahap yang berbeda namun tidak dapat dipisahkan, yaitu nukleasi dan pertumbuhan. Nukleasi merupakan proses pembentukan inti kristal dimana keadaan molekul yang semula tidak teratur menjadi tertata. Adapun, pertumbuhan kristal terjadi setelah nukleasi dengan pembentukan agregat- agregat tertata menjadi molekul yang lebih besar (McPherson dan Gavira, 2014).

Nukleasi dan pertumbuhan kristal sangat tergantung dengan keadaan supersaturasi larutan induk (mother liquor) pembentuk kristal. Supersaturasi merupakan keadaan tidak seimbang dimana beberapa jumlah molekul/ protein melebihi batas kelarutan, namun masih dalam fasa cair. Keseimbangan dapat dicapai kembali dengan pembentukan dan pertumbuhan fasa solid (padat) sebagai kristal, karena batas kejenuhan tercapai (McPherson dan Gavira, 2014).

Metode pemurnian dan kristalisasi protein pada umumnya dilakukan secara bertahap (tidak sinambung). Adapun kristal yang dihasilkan memiliki tingkat kemurnian yang tinggi serta didapatkan dalam jumlah sangat kecil. Sedangkan, enzim yang dibutuhkan industri adalah kristal dalam jumlah besar dengan tingkat kemurnian parsial.

Suatu metode kristalisasi dikembangkan untuk meningkatkan kemurnian dan kestabilan suatu enzim. Crystallizer Sinambung didesain khusus untuk kristalisasi dan pemurnian parsial protein enzim dan protein lain secara sinambung dengan sistem filtrasi. Proses kristalisasi sinambung menggunakan Crystallizer Sinambung ini dapat diaplikasikan untuk pemurnian parsial dan kristalisasi sediaan enzim atau protein lain, dengan penambahan ammonium sulfat atau agen presipitan lain yang sesuai dalam kadar hasil percobaan optimasi (Paten, unpublished).

\section{Metode Penelitian}

\section{Alat dan bahan}

Getah Carica papaya dari buah papaya muda (berumur 2,5-3 bulan) yang tumbuh di wilayah Mulyorejo, Surabaya, yang dilarutkan dalam akuades dingin dengan rasio 1:1 dan diaduk selama 1 jam. Larutan getah ini disentrifuga selama 20 menit dengan kecepatan $9.000 \mathrm{rpm}$ dan 
suhu $4^{\circ} \mathrm{C}$ sehingga didapat supernatan yang merupakan ekstrak papain (Malle dkk., 2015; Malek dkk., 2016).

\section{Fraksinasi ammonium sulfat}

Ekstrak papain ditambahkan ammonium sulfat secara bertahap sesuai dengan tingkat kejenuhan dan diikuti dengan inkubasi dalam es selama minimal 2 jam, kemudian disentrifuga dengan kecepatan $10.000 \mathrm{rpm}$ pada suhu $4{ }^{\circ} \mathrm{C}$ selama 15 menit. Presipitat yang didapat dari setiap sentrifugasi tersebut dilarutkan kembali dalam buffer yang mengandung 0,2 $\mathrm{M}$ fosfat, $\mathrm{pH} 6$ hingga tepat larut. Langkah-langkah tersebut dilakukan untuk ammonium sulfat dengan kejenuhan $40 \%$ dan 40-80\%. Adapun presipitat yang telah dilarutkan tersebut didialisis dengan buffer fosfat $0,05 \mathrm{M}$ pH 6 sehingga dapat dilakukan uji selanjutnya (Purwanto, 2016).

\section{Penentuan kadar protein}

$\begin{array}{rrr} & \text { Kadar protein dalam sampel } \\ \text { selama } & \text { pemurnian } & \text { ditentukan }\end{array}$ menggunakan metode Bradford dengan kurva standar larutan BSA $1 \mathrm{mg} / \mathrm{mL}$ (Purwanto, 2016). Sampel enzim sebanyak $20 \mu \mathrm{L}$ ditambahkan akuades hingga 600 $\mu \mathrm{L}$ dan larutan Bradford $500 \mu \mathrm{L}$, lalu didiamkan selama 5 menit, pada suhu ruang. Absorbansi sampel diukur pada panjang gelombang $595 \mathrm{~nm}$ (Rosenberg, 2005).

\section{Penentuan aktivitas protease}

Penentuan aktivitas protease dilakukan menggunakan kurva standar dari larutan induk tirosin $100 \mu \mathrm{g} / \mathrm{mL}$ dalam $\mathrm{HCl} 0,2 \mathrm{~N}$. Suatu campuran reaksi uji terdiri dari substrat kasein $1 \%$ sebanyak $400 \mu \mathrm{L}$ dan ektrak enzim sebanyak $20 \mu \mathrm{L}$, lalu ditambahkan buffer fosfat $0,05 \mathrm{M} \mathrm{pH}$ 6 hingga volume $900 \mu \mathrm{L}$. Campuran tersebut diinkubasi pada suhu $65{ }^{\circ} \mathrm{C}$ selama 5 menit. Reaksi dihentikan dengan menambahkan 3 mL TCA 5\%. Campuran disentrifuga dan diukur absorbansinya pada panjang gelombang $275 \mathrm{~nm}$. Pengukuran ini juga dilakukan terhadap blanko tanpa adanya ekstrak enzim. Aktivitas protease diukur berdasarkan kadar tirosin yang terbaca (Purwanto, 2016).

$$
\text { Aktivitas protease }(U / m L)=\frac{\text { konsentrasi tirosin } \times \text { Vlarutan uji }}{\text { Mr tirosin } \times \text { waktu inkubasi } \times \text { V enzim }}
$$

\section{Optimasi kristalisasi fraksi papain}

Fraksi dengan aktivitas spesifik terbaik, dikristalisasi dengan penambahan ammonium sulfat. Kadar ammonium sulfat untuk kristalisasi dioptimasi berdasarkan data kadar ammonium sulfat pada saat fraksinasi papain, yaitu dengan tingkat kejenuhan 20\%, 30\%, 40\%, 50\%, 55\%, $60 \%, 70 \%$, dan $80 \%$. Kristalisasi ini dilakukan dengan inkubasi pada suhu 5, 15,25 , dan $30^{\circ} \mathrm{C}$ hingga terbentuk kristal papain secara perlahan. Kristal papain yang terbentuk dipisahkan dengan supernatannya, kemudian diamati secara makroskopis dan mikroskopis serta diuji aktivitas proteasenya.

\section{SDS-PAGE}

SDS-PAGE pada penelitian ini bertujuan untuk membandingkan papain sebelum dan sesudah dimurnikan secara parsial melalui pita papain pada gel. Pita papain ditentukan berat molekulnya berdasarkan pembanding marker. SDS-PAGE dilakukan menggunakan akrilamida $12 \%$ (Purwanto, 2016). Sampel disiapkan dalam loading buffer tris/ gliserol/ $\beta$ merkaptoetanol, kemudian diletakkan dalam air mendidih selama 10 menit dan dielektroforesis dengan $100 \mathrm{~V}$ selama 60 menit. Pewarnaan gel menggunakan Coomasie-Blue R-250.

\section{Hasil dan Pembahasan}


Preparasi ekstrak papain dari getah Carica papaya

Getah Carica papaya diperoleh dari penyayatan kulit buah papaya muda yang berumur 2,5-3 bulan. Menurut penelitian Malek dkk. (2016), semakin hijau (muda) buah papaya, akan diperoleh papain yang semakin banyak karena jumlah pati dan gula pada buah masih rendah pada 11 minggu (2,5-3bulan) pertama. Penyayatan dilakukan pada pagi hari untuk menghindari reaksi fotosintesis dan polusi udara yang mungkin terjadi. Empat buah pepaya muda dari pohon yang sama menghasilkan getah sebanyak 25,6916 g. Getah dikumpulkan dalam sebuah wadah plastik bertutup dan disimpan dalam freezer sampai digunakan untuk menghindari reaksi yang dapat menurunkan aktivitas enzim.

Papain merupakan protein globular sehingga dapat dilarutkan dalam air dengan mudah. Digunakan akuades dingin sebagai pelarut untuk menjaga kualitas papain selama proses ekstraksi. Larutan getah ini disentrifuga selama 20 menit dengan kecepatan 9.000 rpm dengan suhu $4{ }^{\circ} \mathrm{C}$. Presipitat merupakan komponen yang tidak digunakan, sedangkan supernatan merupakan ekstrak papain. Diperoleh ekstrak papain sebanyak $31 \mathrm{~mL}$.

\section{Fraksinasi papain dari getah Carica papaya}

Fraksinasi bertujuan memisahkan sebagian besar senyawa pengotor, baik protein maupun bukan protein dari protein target. Fraksi papain diperoleh dari ekstrak papain sebanyak $31 \mathrm{~mL}$ dengan penambahan ammonium sulfat secara bertahap dengan tingkat kejenuhan $40 \%$ dan $40-80 \%$.

Berdasarkan hasil uji aktivitas spesifik protease sebagaimana pada Tabel 3.1, dapat disimpulkan bahwa aktivitas spesifik paling tinggi terdapat pada fraksi papain $40-80 \%$ dengan faktor kemurnian meningkat 6,86 kali dari ekstrak papain.

Fraksi $0-40 \%$ menunjukkan aktivitas protease yang jauh lebih rendah dibanding fraksi 40-80\%. Namun aktivitas spesifik fraksi $0-40 \%$ sangat rendah. Hal ini menunjukkan pada fraksi $0-40 \%$ mengandung banyak protein pengotor. Adapun aktivitas spesifik pada supernatan hampir mendekati nol. Sehingga, dapat ditarik kesimpulan bahwa papain terdapat pada fraksi $40-80 \%$.

\section{Optimasi Kristalisasi Fraksi Papain}

Pengamatan secara makroskopis dilakukan melalui pengamatan pembentukan presipitat pada masingmasing tabung. Data hasil pengamatan disajikan pada Tabel 3.2.

Pengamatan secara mikroskopis pada keseluruhan tabung yang memiliki presipitat menunjukkan kristal kubus dan tetragonal. Selain dilakukan terhadap sampel, pengamatan ini dilakukan terhadap blanko yang mengandung ammonium sulfat sebagai perbandingan bentuk kristal. Adapun kristal ammonium sulfat pada kondisi kristalisasi ini cenderung berbentuk bulat (Gambar 3.1).

Aktivitas protease masingmasing kristal yang diperoleh dengan menggunakan presipitan ammonium sulfat $55-70 \%$ cukup rendah, dan aktivitas protease yang tertinggal di supernatan cukup tinggi. Hal ini berhubungan dengan ketidaksempurnaan kristalisasi yang menggunakan presipitan ammonium sulfat 55-70\%. Adapun presipitan ammonium sulfat $80 \%$ pada suhu $15^{\circ} \mathrm{C}$ menghasilkan kristal dengan aktivitas protease paling tinggi. Presipitan ammonium sulfat $80 \%$ pada suhu $30{ }^{\circ} \mathrm{C}$ menghasilkan kristal maupun supernatan dengan aktivitas protease lebih rendah, diduga berkaitan dengan kestabilan enzim terhadap suhu (Tabel 3.3). 
$S D S-P A G E$

Sampel yang diuji menggunakan SDS-PAGE meliputi ekstrak papain, fraksi papain (fraksi 40-80\%) dengan berbagai pengenceran dan volume, serta kristal papain yang dihasilkan dari presipitan ammonium sulfat $80 \%$ pada suhu $15^{\circ} \mathrm{C}$. Adapun gel yang digunakan dalam SDSPAGE ini adalah $12 \%$ akrilamida, yang dapat memisahkan protein dengan berat molekul $\sim 15 \mathrm{kDa}$ hingga $\sim 120 \mathrm{kDa}$.

SDS-PAGE pada percobaan ini menunjukkan adanya pemurnian ekstrak papain secara parsial melalui berkuranganya pita-pita yang tampak pada gel dari Gambar 3.2 (b) menjadi Gambar 3.2 (c). Adapun pita pada kristal papain (Gambar 3.2 (a)) tampak tebal dibandingkan dengan pita fraksi papain (fraksi 40-80\%). Hal ini dikarenakan kristal papain yang lebih pekat serta volume yang dimasukkan ke dalam sumur gel lebih banyak dari pada fraksi papain (fraksi 40-80\%). (b)

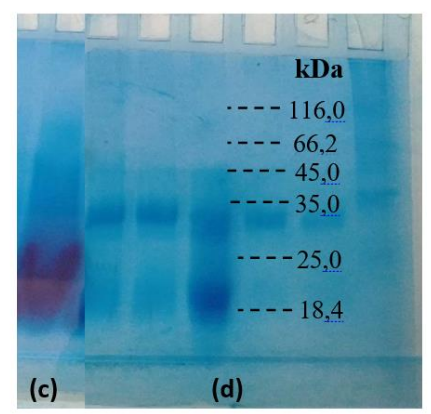

Gambar 3.2 (a) Kristal Papain (b) Ekstrak Papain (c) Fraksi Papain dengan berbagai Pengenceran dan Volume (d) Marker Protein

Pita papain ditentukan berat molekulnya berdasarkan pembanding marker dan perhitungan $R_{f}$ melalui kurva standart. $\mathrm{R}_{\mathrm{f}}$ merupakan perbandingan jarak migrasi pita dengan jarak migrasi loading buffer. Berdasarkan penentuan berat molekulnya, diketahui bahwa sampel yang digunakan pada penelitian ini memiliki kandungan papain dengan berat molekul $\sim 23 \mathrm{kDa}$.

Tabel 3.1 Data Hasil Fraksinasi Papain dari Getah Carica papaya

\begin{tabular}{|l|c|c|c|c|c|c|}
\hline \multicolumn{1}{|c|}{ Sampel } & $\begin{array}{c}\text { Aktivitas } \\
\text { Protease } \\
(\mathbf{U} / \mathbf{m L})\end{array}$ & $\begin{array}{c}\text { Volume } \\
(\mathbf{m L})\end{array}$ & $\begin{array}{c}\text { Aktivitas } \\
\text { Total }(\mathbf{U})\end{array}$ & $\begin{array}{c}\text { Kadar } \\
\text { Protein } \\
\text { Total }(\boldsymbol{\mu g})\end{array}$ & $\begin{array}{c}\text { Aktivitas } \\
\text { Spesifik } \\
(\mathbf{U} / \boldsymbol{\mu g})\end{array}$ & $\begin{array}{c}\text { Faktor } \\
\text { Ke- } \\
\text { murnian }\end{array}$ \\
\hline $\begin{array}{l}\text { Ekstrak } \\
\text { papain }\end{array}$ & 237,1351 & 31 & $7.351,1881$ & $22.151,9321$ & 0,3318 & 1,00 \\
\hline Fraksi 0-40\% & 2,7123 & 1,2 & 3,2547 & 5,9375 & 0,5482 & 1,65 \\
\hline Fraksi 40-80\% & 382,7962 & 31,9 & $12.246,4175$ & $5.882,3690$ & 2,0819 & 6,27 \\
\hline Supernatan & 0,0584 & 113,1 & 6,5983 & 139,0788 & 0,0475 & 0,14 \\
\hline
\end{tabular}

Tabel 3.2 Hasil Pengamatan Makroskopis Pembentukan Presipitat Fraksi Papain

\section{Kondisi} Hasil Pengamatan pada Hari ke- 


\begin{tabular}{|c|c|c|c|c|c|c|c|}
\hline $\begin{array}{c}\text { Suhu } \\
\left({ }^{\circ} \mathbf{C}\right)\end{array}$ & $\begin{array}{c}\text { Ammonium } \\
\text { Sulfat }(\%)\end{array}$ & $1-3$ & $4-6$ & $5-8$ & $9-12$ & $13-15$ & $16-18$ \\
\hline \multirow{7}{*}{5} & 20 & - & - & - & - & - & - \\
\hline & 30 & - & - & - & - & - & - \\
\hline & 40 & - & - & - & - & - & - \\
\hline & 50 & - & - & - & - & - & - \\
\hline & 55 & - & - & ++ & ++ & ++ & ++ \\
\hline & 60 & +++ & +++ & +++ & +++ & +++ & +++ \\
\hline & 70 & +++++ & +++++ & +++++ & +++++ & +++++ & +++++ \\
\hline \multirow{8}{*}{15} & 20 & - & - & - & - & - & - \\
\hline & 30 & - & - & - & - & - & - \\
\hline & 40 & - & - & - & - & - & - \\
\hline & 50 & - & - & - & - & +++ & - \\
\hline & 55 & - & - & ++++ & ++++ & ++++ & ++++ \\
\hline & 60 & +++ & +++ & +++ & +++ & +++ & +++ \\
\hline & 70 & +++++ & +++++ & +++++ & +++++ & +++++ & +++++ \\
\hline & 80 & +++++ & +++++ & +++++ & +++++ & +++++ & +++++ \\
\hline \multirow{4}{*}{25} & 20 & - & - & - & - & - & - \\
\hline & 30 & - & - & - & - & - & - \\
\hline & 40 & - & - & - & - & - & - \\
\hline & 50 & - & - & - & - & - & - \\
\hline \multicolumn{2}{|r|}{ Kondisi } & \multicolumn{6}{|c|}{ Hasil Pengamatan pada Hari ke- } \\
\hline $\begin{array}{l}\text { Suhu } \\
\left({ }^{\circ} \mathbf{C}\right)\end{array}$ & $\begin{array}{l}\text { Ammonium } \\
\text { Sulfat (\%) }\end{array}$ & $1-3$ & 4-6 & $5-8$ & $9-12$ & 13-15 & 16-18 \\
\hline \multirow{3}{*}{25} & 55 & - & - & - & - & - & - \\
\hline & 60 & +++ & +++ & +++ & +++ & +++ & +++ \\
\hline & 70 & +++++ & +++++ & +++++ & +++++ & +++++ & +++++ \\
\hline
\end{tabular}




\begin{tabular}{|c|c|c|c|c|c|c|c|}
\hline 30 & 80 & +++++ & +++++ & +++++ & +++++ & +++++ & +++++ \\
\hline
\end{tabular}

Keterangan: + : terbentuk larutan koloidal atau suspense atau presipitat

- : larutan bening

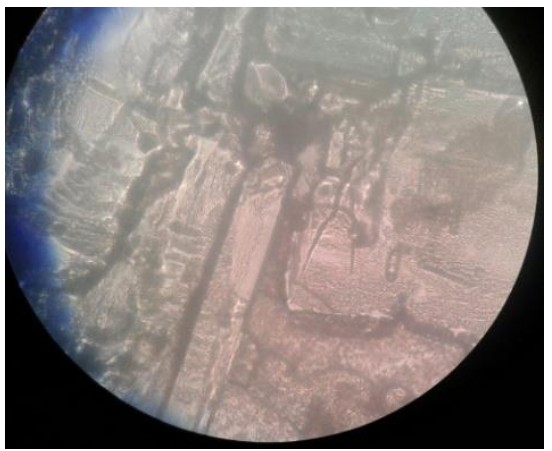

(a)

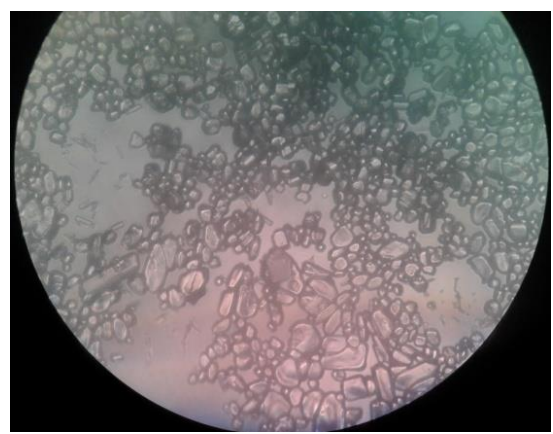

(c)

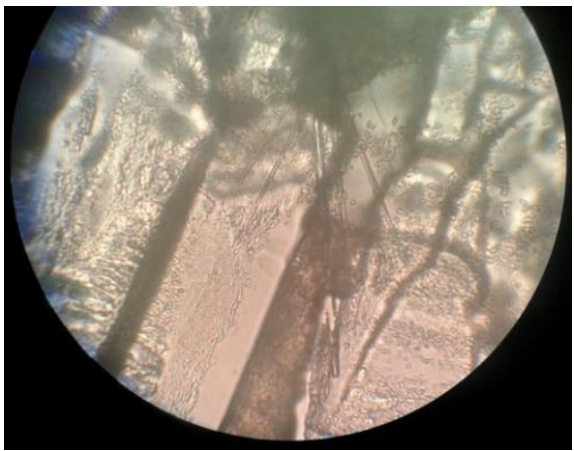

(b)

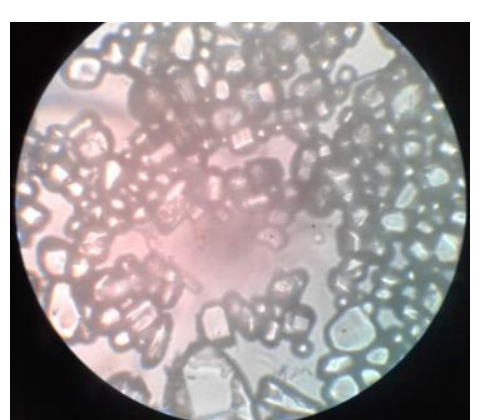

(d)

Gambar 4.2 (a) Kristal Papain Perbesaran 400x (b) Kristal Papain Perbesaran 1.000x (c) Kristal Ammonium Sulfat Perbesaran 400x (d) Kristal Ammonium Sulfat Perbesaran 1.000x

Tabel 3.3 Hasil Optimasi Kristalisasi Fraksi Papain

\begin{tabular}{|c|c|c|c|c|c|}
\hline \multicolumn{2}{|c|}{ Kondisi } & \multirow{2}{*}{ Sampel } & \multirow{2}{*}{$\begin{array}{c}\text { Aktivitas } \\
\text { Protease } \\
(\mathrm{U} / \mathbf{m L})\end{array}$} & \multirow{2}{*}{$\begin{array}{l}\text { Volume }^{* * *} \\
\quad(\mathrm{~mL})\end{array}$} & \multirow{2}{*}{$\begin{array}{l}\text { Aktivitas } \\
\text { Total (U) }\end{array}$} \\
\hline $\begin{array}{c}\text { Suhu } \\
\left({ }^{\circ} \mathrm{C}\right)\end{array}$ & $\begin{array}{c}\text { Ammonium } \\
\text { Sulfat }(\%)\end{array}$ & & & & \\
\hline \multirow{6}{*}{5} & \multirow{2}{*}{55} & Kristal & 3,3988 & 0,13 & 0,4418 \\
\hline & & Supernatan & 4,3132 & 0,32 & 1,3802 \\
\hline & \multirow{2}{*}{60} & Kristal & 2,1412 & 0,20 & 0,4282 \\
\hline & & Supernatan & 3,2074 & 0,85 & 2,7263 \\
\hline & \multirow{2}{*}{70} & Kristal & 4,3429 & 0,30 & 1,3802 \\
\hline & & Supernatan & 4,5145 & 0,80 & 3,6116 \\
\hline 15 & 55 & Kristal & 4,7060 & 0,27 & 1,2706 \\
\hline
\end{tabular}




\begin{tabular}{|c|c|c|c|c|c|}
\hline & & Supernatan & 3,8379 & 0,30 & 1,1514 \\
\hline & \multirow{2}{*}{60} & Kristal & 4,2868 & 0,20 & 0,8574 \\
\hline & & Supernatan & $-*$ & $-*$ & $-*$ \\
\hline & \multirow{2}{*}{70} & Kristal & 4,1680 & 0,23 & 0,9586 \\
\hline & & Supernatan & $-*$ & $-*$ & $-*$ \\
\hline & \multirow{2}{*}{80} & Kristal & 71,8535 & 0,15 & 10,7780 \\
\hline & & Supernatan & 0,5139 & 0,12 & 0,0642 \\
\hline \multirow{4}{*}{25} & \multirow{2}{*}{60} & Kristal & $-*$ & $-*$ & $-*$ \\
\hline & & Supernatan & 4,5079 & 0,13 & 0,5860 \\
\hline & \multirow{2}{*}{70} & Kristal & 2,8047 & 0,30 & 0,8414 \\
\hline & & Supernatan & $-*$ & $-*$ & $-*$ \\
\hline \multirow{2}{*}{30} & \multirow{2}{*}{80} & Kristal & 51,0580 & 0,15 & 7,6587 \\
\hline & & Supernatan & 0,0518 & 0,12 & 0,0064 \\
\hline
\end{tabular}

*Beberapa data tidak didapatkan karena keterbatasan sampel

** Volume larutan enzim hasil pelarutan kristal

Kesimpulan

Dari penelitian ini, dapat ditarik kesimpulan bahwa fraksi papain pada proses fraksinasi getah Carica papaya adalah fraksi $40-80 \%$ ammonium sulfat dengan peningkatan faktor kemurnian 6,27 kali lebih besar daripada ekstrak papain. Selain itu, kristalisasi papain dapat dihasilkan secara optimum dengan penambahan presipitan ammonium sulfat $80 \%$ jenuh pada suhu $15{ }^{\circ} \mathrm{C}$. Adapun kristal papain dari fraksi $40-80 \%$ yang diperoleh berbentuk kubus dan tetragonal.

\section{Daftar Pustaka}

Baktir, A., 2018, Prototipe dan Penggunaan Kristaliser Protein untuk Kristalisasi dan Pemurnian Parsial Protein/ Enzim secara Sinambung, Paten, Unpublished, Indonesia
Metode fraksinasi untuk mendapatkan kristal papain dengan tingkat kemurnian parsial dari getah Carica papaya dapat diaplikasikan dalam Crystallizer Sinambung dengan kadar ammonium sulfat sesuai hasil percobaan optimasi pada penelitian ini. Selanjutnya, penelitian ini dapat dikembangkan dan diterapkan untuk enzim-enzim lain yang potensial sebagai alternatif pemenuhan kebutuhan enzim di Indonesia.

Gunde, M.C., dan Amnerkar, N.D., 2016, Nutritional, Medicinal and Pharmacological Properties of Papaya (Carica papaya linn.): A Review, JIPBS, 3, 162-169

Kementerian Pertanian, 2015, Statistik Produksi Hortikultura Tahun 
2014, Direktorat Jenderal Hortikultura, Kementerian Pertanian, Indonesia

Llerena-Suster, C.R., Jose, C., Collins, S.E., Briand, L.E., dan Morcelle, S.R., 2012, Investigation of the Structure and Proteolytic Activity of Papain Miscible Organic Media, Process Biochemistry, 47, 47-56

Malek, K., Norazan, M., Ramaness, P., Othman, N.Z., Malek, R., Aziz, R., Aladdin, dan A., El-Enshasy, H., 2016, Cysteine Protease from Carica papaya: An important enzyme group of many industrial applications, IOSR-JPBS, 11, 1116

McPherson, A., dan Gavira, J. A., 2014, Introduction to Protein Crystallization, Acta Cryst., F70, 2-20Sutandi, C., 2003, Analisis Potensi Enzim Protease Lokal, Skripsi, IPB, Indonesia

Patel, T., 2016, Papain Enzyme: A Digestive Aid, Int. J. Clin. and Biomed. Res., 2, 52-53Zusfahair, Ningsih, D.R., dan Habibah, F.N., 2014, Karakterisasi Papain dari Daun Pepaya (Carica papaya 1.), Molekul, 9, 44-55

Purwanto, M.G.M., 2016, The Role and Efficiency of Ammonium Sulphate Precipitation in Purification of Papain Ekstrak papain Extract, Procedia Chemistry, 18, 127-131

Scopes, R. K., 2013, Protein Purification: Principles and Practice, $2^{\text {nd }}$ Edition, Springer Science \& Business Media, USA

Sutandi, C., 2003, Analisis Potensi Enzim Protease Lokal, Skripsi, IPB, Indonesia

Zusfahair, Ningsih, D.R., dan Habibah, F.N., 2014, Karakterisasi Papain dari Daun Pepaya (Carica papaya 1.), Molekul, 9, 44-55 